Russian Literature XXXIX (1996) 95-114

North-Holland

\title{
THE END IN V. EROFEEV'S MOSKVA-PETUŠKI
}

\author{
VLADIMIR TUMANOV
}

Наш паровоз вперед лети - в коммуне остановка...

One of the most striking and unsettling elements in Venedikt Erofeev's novel Moskva-Petuški is the ending where Venja, the protagonist-narrator, is murdered by four mysterious executioners in the stairway of a downtown Moscow building. These are the hero's last words as he narrates his own death:

Они вонзили мне шило в самое горло [...]. Я не знал, что есть на свете такая боль. Я скрючился от муки, густая красная буква "ю" распласталась у меня в глазах и задрожала. И с тех пор я не приходил в сознание, и никогда не приду.

(1989: 506)

The last sentence turns the entire preceding narrative into a paradox: the narrator indicates that he could not have told his story, since he ceased to exist as a consciousness ("soznanie") as soon as the action stopped. The fact of Venja's death itself does not necessarily cancel out his ability to tell about the events leading up to his demise: literature knows a number of beyondthe-grave narrators, e.g., the murdered Olivia in Anne Hébert's Les Fous de Bassan or the dead samurai Tekehiko in Akutagawa Riunosuke's 'In a Grove'. What makes Venja's narrative paradoxic is his own reference to the end of his cogitative activity: at the moment of death the hero ceases to think 
and should, logically, lose the ability to narrate. Normally, a dead narrator acquires his/her ability to narrate by supernatural means, e.g., via life after death, as in Les Fous de Bassan or through a medium, as in 'In a Grove'. Such postmortem loquacity may also remain unexplained. In MoskvaPetuški, however, the dead narrator seems to stress that his death appears as the ultimate end: a point where everything, including time and consciousness, stops.

By depriving himself of consciousness after death, Venja deprives himself of what B. Romberg calls the "epic situation". Romberg argues that in first-person narrative - and especially when the narrator is also the protagonist - we are normally given the particulars of the narrating situation and some kind of motivation for the narrative act, i.e., when where, how and possibly why the narrator is telling his/her story (Romberg 1962: 33). Thus, Adso's epic situation in Umberto Eco's The Name of the Rose is that of an old man looking back at a certain series of events from his younger days. When Adso writes, "it is cold in the scriptorium, my thumb aches. I leave this manuscript, I do not know for whom [...]" (1984: 611), his epic situation is foregrounded: we know where the epos is taking place (in a scriptorium) and in what form (writing). Because the ending of Moskva-Petuski makes it clear that Erofeev's narrator is utopic and achronic, i.e., existing in no place and in no time, he has no situation as a speaking instance. Therefore, the questions where, when, how and why are not and, what is most important, cannot be logically answered with respect to Venja's narrative act.

Venja's absent epic situation is part of a larger narratological issue first discussed by E. Benveniste as the difference between discours and histoire, i.e., the plane of the telling and the plane of the told respectively (Benveniste 1966: 238-242). The key element of this dichotomy is a temporal one, which is why Benveniste integrates it into his analysis of French verb tenses. As S. Chatman puts it:

if the narrative is overt, there are perforce two NOWs, that of the discourse, the moment occupied by the narrator in the present tense ("I am going to tell you the following story"), and that of the story, the moment that the action began to transpire, usually in the preterite. (Chatman 1978: 63) ${ }^{1}$

Thus, any first-person narrator who takes part in the events of his/her story has two possible referents for the pronoun "I": I-then and I-now. If we look at Venja's narrative from the last sentence backwards, it has no I-now plane and therefore, paradoxically, no discourse.

If, on the other hand, we leave the "impossible" ending aside, the story and discourse levels appear to be present in Moskva-Petuski. However, the relationship between the narrator's I-now and I-then is no less paradoxic than 
his final self-annihilating statement. As Chatman points out, a narrator's present "remains posterior to that of the characters" including that of his own I-then (1978: 83). This means that I-now and I-then cannot logically share the same moment in time: in Moskva-Petuški they do just that, since throughout the first half of the text the posteriority of the I-now with respect to the time of the I-then seems to be repeatedly violated. This intersection of the I-now and the I-then planes appears as a violation because in much of Venja's narrative the discourse level does seem to be posterior to the story level.

The narrative begins within the plane of the I-now: "Vse govorjat: Kreml', Kreml'. Oto vsech ja slyšu pro nego, a sam ni razu ne videl" (1989: 419). This seems to be a reference to the protagonist's state at the moment of discourse, i.e., after all the events in the story. Switching to the temporal level of his I-then, Venja proceeds to tell about what he refers to as "vcera": "Vot $i$ včera opjat' ne uvidel, - a ved' celyj večer krutilsja vokrug tech mest [...]" (1989: 419). Then he tells about the hangover experienced by him on the morning of his trip, his unsuccessful attempt to get a drink of sherry at the Kursk train station restaurant and his painful walk toward the train which is to take him to Petuski:

Что было потом - от ресторана до магазина и от магазина до поезда - человеческий язык не повернется выразить. Я тоже не берусь. А если за это возьмутся ангелы - они просто расплачутся, а сказать ничего не сумеют. Давайте лучше так давайте почтим минутой молчания два этих смертных часа.

(1989: 424)

So far the I-now ("davajte poctim minutoj molčanija") appears to be posterior to the I-then ("cto bylo potom"), which is a normal narrative sequence. However, suddenly Venja shifts into a communicative mode that causes these two temporal levels to fuse:

\begin{abstract}
Я обращаюсь ко всем родным и близким [...] Оставьте ваши занятия. Остановитесь вместе со мной, и почтим минутой молчания то, что невыразимо. Если есть у вас под рукой какой-нибудь завалящий гудок - нажмите на этот гудок. Так. Я тоже останавливаюсь... Ровно минуту, мутно глядя в вокзальные часы, я стою как столб посреди площади Курского вокзала.
\end{abstract}

(1989:424)

The request that the reader stop for a moment of silence in honor of the "epic hangover" can come only from Venja the narrator, i.e., his I-now. However, this appears to intersect in time with the stop made by Venja the character, i.e., his I-then, in the middle of the Kursk station. 
The same paradoxic simultaneity of Venja's story and discourse appears repeatedly in the narrative of the train ride. For example, as Venja enters his train compartment after having temporarily left it for yet another drink, the attention of his I-then is caught by his fellow-passengers:

Я кое-как пригладил волосы и вернулся в вагон. Публика посмотрела в меня почти безучастно, круглыми и как будто ничем не занятыми глазами...

(1989: 427)

Then his I-now makes a comment about the vacuous stare of the other passengers observed by the I-then:

Мне это нравится. Мне нравится, что у народа моей страны глаза такие пустые и выпуклые. [...] Мне нравится мой народ. Я счастлив, что родился и возмужал под взглядом этих глаз. Плохо только вот что: вдруг да они заметили, что я сейчас там на площадке выделывал?

$(1989: 427-428)$

Through the phrase "plocho tol'ko vot čto" the moment in time occupied by Venja the narrator ceases to be posterior to the moment in time occupied by Venja the character entering his compartment. Therefore, the adverb "sejcas" has two simultaneous and mutually exclusive referents. Similarly, when Venja suspects his fellow-passengers of stealing his liquor ("Poceluj teti Klavy") in his absence, he conflates the story and discourse levels, bringing the reader's time into the time of the narrated events:

Пока я делился с вами восторгом моего чувства, пока посвяцал вас в тайны бытия, - меня тем временем лишили "Поцелуя тети Клавы”. [...] В простоте душевной я ни разу не заглянул в вагон все это время.

$(1989: 454)$

Thus, in the same manner as in the case of the adverb "sejcas" in the previously cited passage, the phrase "tem vremenem" acts as a paradoxic pivoting mechanism linking two mutually exclusive temporal domains.

An even more striking intersection of story and discourse time occurs when the temporal position of the I-now appears first simultaneous and then anterior with respect to the point in time occupied by the I-then. Addressing the reader, Venja once again uses an ambiguous "sejčas":

Да! Где это мы сейчас едем?.. Кусково! Мы чешем без остановки через Кусково! По такому случаюо следовало бы мне 
еще раз выпить, но я лучше сначала вам расскажу, КУСКОВОНОВОГИРЕЕВО а потом уж пойду и выпью.

(1989:431)

The future tense indicates that at the moment when Venja the narrator is addressing the reader, Venja the character has not yet taken this drink. However, a number of pages later, the drink occurs in the past tense, i.e., at the level of the I-then:

И вот - я снова встал и через половину вагона пошел на площадку. И пил уже не так, как пил у Карачарова, нет, теперь я пил без тошноты и без бутерброда [...].

(1989:437)

This lack of temporal differentiation between the I-now and the I-then is all the more paradoxic since there are several indications that Venja's narrative is written. When, for example, he tells the story of his work as a cable installation brigade leader at the Sheremetyevo airport, Venja describes his system of drinking graphs corresponding to each worker in his brigade:

Сказать ли вам, что это были за графики? Ну, это очень просто: на веленевой бумаге, черной тушью, рисуются две оси - одна ось горизонтальная, другая вертикальная. На горизонтальной откладываются последовательно все рабочие дни истекшего месяца, а на вертикальной - количество выпитых граммов, в пересчете на чистый алкоголь. [...] Вот, полюбуйтесь, например, это линия комсомольца Виктора Тотошкина [...].

$(1989: 435)$

What follows is the actual graph reproduced (drawn) within the text, which clearly indicates that Venja's narrative act could not be simultaneous with any of the events being narrated.

However, just as the story and discourse levels in this text appear to be discrete and yet simultaneous at the same time, Venja's narrative turns out to be both written and oral, which fits in quite nicely with the general paradoxic framework of Moskva-Petuski. Thus, even though the narrator's alcoholic graphs seem to indicate that Venja's discourse must be written, his alcoholic recipes turn it into an oral narrative. The following is a recipe for "Sučij potroch" - a cocktail of the hero's own invention:

Пиво жигулевское - 100 г.; ШІампунь "Садко - богатый гость" - 30 г.; Резоль для очистки волос от перхоти - 70 г.; Клей БФ 12 г.; Тормозная жидкость - 35 г.; Дезинсекталь для унич- 
тожения мелких насекомых - 20 г. [...] Вы хоть что-нибудь записать успели? Ну вот, пока и довольно с вас... А в Петушках - в Петушках я обещаю поделиться с вами секретом "Иорданских струћ", если доберусь живым; если милостив Бог.

(1989: 453)

It is clear that in spite of the aforementioned graphs, this discourse is oral, since the reader can lack the time to write the recipe down only if it is being dictated. Here too the temporal positions of the I-now and the I-then intersect, since the narrator's address to the reader and the train ride appear to be simultaneous: "Vy chot' čto-nibud' zapisat' uspeli?" And, to quote D. Cohn, "when the form of a text imitates written memoirs, oral reports, or diary entries, any action conveyed simultaneously is illogical" (Cohn 1978: 215). Thus, whether written or oral, Venja's narrative does not correspond to any recognizable communicative model.

The above-cited recipe passage introduces yet another paradoxic twist into Venja's tale, which brings us to the "impossible" ending of MoskvaPetuški. Not only is the stop at Petuški treated with respect to Venja's discourse time as an event in the future, but Venja also appears not to know the outcome of his own story: "A v Petuškach $-\mathrm{v}$ Petuškach ja obeščaju podelit'sja s vami sekretom 'Iordanskich struj', esli doberus' Živym; esli milostiv Bog." It would be logical to assume that Venja the narrator - as any retrospectively-oriented speaker - knows how his story ends, which is an advantage that all narrators have over their characters or over their own Ithen. Only a diarist would not possess this knowledge with respect to all of his/her entries taken together. However, not only is there no indication that Venja is writing a diary, but there are even some instances where the hero appears to possess the retrospective knowledge of a traditional narrator. For example, when narrating the approach of his four executioners, Venja the narrator seems to know that Venja the character is about to die: "I tut načalas' istorija, strašnee vsech, vidennych vo sne. V ètom samom pereulke navstreču mne šli četvero" (1989: 503). And Venja's comment about his attempt to escape the killers is even more indicative that at least at this point in the narrative his I-now is looking at the whole story retrospectively and knows what must finally happen to the doomed I-then: "Vse-taki do samogo poslednego mgnovenija ja ešče rassčityval ot nich spastis"' (1989: 505). However, this appears to coexist in the text with the narrator's blissful ignorance of his terrible end. Thus, promising to renounce forever his alcoholic graphs which caused him to be fired from his job, Venja's I-now proclaims: "I vot - ja toržestvenno ob"javljaju: do konca moich dnej ja ne predprimu ničego, čtoby povtorit' moj pečal'nyj opyt vozvyšenija" (1989: 435). Perhaps Venja the narrator's puzzling statements about his future can 
be accounted for via the recurring paradoxic temporal fusion of his story and discourse levels and especially via the "impossible" ending: having ceased to exist as a consciousness, the I-now cannot be expected to know anything even the fact of his own death. However illogical this "logic" may appear, it seems to be the only way of attempting to reconcile the irreconcilable.

Venja's inside-out narrative suggests a narrator for whom time has stopped: a hero who seems to exist somewhere outside of existence and is therefore not constrained by its temporal or sequential parameters. In order to offer an interpretation of Venja's "nowhereness" I would like to return to the end of his narrative which is also "the end" of the hero. It seems that Venja has not just died: his trip has brought him not just to the end of his life but to the end of everything. And in this respect the ending of Moskva-Petuški recalls that most final of all endings: the Apocalypse. This would imply that the narrator addresses the reader not from beyond the grave but from beyond history.

The apocalyptic nature of this novel is mentioned in D. Bethea's seminal study of the Apocalypse in Russian literature: "One of the most important post-Thaw novels is Venedikt Erofeev's tragicomic From Moscow to the End of the Line (Moskva-Petushki, 1976). This work revives many of the same themes and structural principles found in the earlier 'apocalyptic fictions', only the element of parody is now much stronger" (Bethea 1989: 274). Placing Erofeev's novel into a long tradition of Russian apocalypticism, Bethea demonstrates the importance of eschatological thought in Russia's cultural history and the extent to which the last book of The New Testament, the Revelation of John, has influenced the imagination of many Russian philosophers and especially authors.

To begin with, Bethea argues that the role of Moscow as the Third Rome - an idea which goes back to the beginning of the sixteenth century has been "a fertile source of the kind of end-determined, 'right-angled' view of national history perpetuated by later writers, social theorists, and public figures" (1989: 15). With the fall of Constantinople to the Turks in 1453 it was widely believed that Moscow with its holy ruler (basileus) was now the last messianic center of the world that would lead humanity into the millennium. However, as Bethea goes on to point out, with the Schism of the 1660s large strata of Russian society saw Nikon's reforms as the betrayal of Moscow's messianic role:

If Moscow was turning its back on its heritage as the Third Rome, then there was only one conclusion to draw - it was not the holy but the unholy city, the seat of the Antichrist. [...] In the words of the Old Believer monk Avraamy, "There will no longer be any further delay; everywhere is Russia's last [moment] [...]".

(Bethea 1989: 20) 
In other words Moscow became associated with the forces that would confront the army of Christ at Armageddon.

The centrality of Moscow in Moskva-Petuški is evident already from the title. In the text itself Moscow is the site of Venja's Apocalypse and therefore the city of The End. It appears clearly as an evil city, which Venja tries to flee in the direction of Petuski. Petuski, on the other hand, is repeatedly referred to in terms that evoke images of Paradise or New Jerusalem:

Oн [God - V.T.] благ. Он ведет меня от страданий - к свету. От Москвы - К Петушкам. Через муки на Курском вокзале, через очищение в Кучине, через грезы в Купавне - к свету и Петушкам.

$(1989: 450)^{2}$

And especially evocative of Eden are Venja's repeated references to Petuški as a paradisiac garden:

Петушки - это место, где не умолкают птицы ни днем ни ночью, где ни зимой, ни летом не отцветает жасмин. Первородный грех - может, он и был - там никого не тяготит. Там даже у тех, кто не просыхает по неделям, взгляд бездонен и ясен [...].

$(1989: 436)$

The above-mentioned idea that Moscow, as the fallen Third Rome, is the seat of the Antichrist and therefore a Godless city comes to mind when Venja raises the question of God's presence in Moscow and Petuski:

Он обогнул это место [Moscow - V.T.] и прошел его стороной. Нет, это не Петушки! Петушки Он стороной не обходил. Он, усталый, ночевал там при свете костра [...].

(1989: 504)

This clearly demonstrates that Moscow and Petuški are as opposite as the Whore of Babylon and the New Jerusalem, and it is for the latter that Venja yearns.

However, Moscow appears as inevitable as The End, and the hero never makes it to his paradise: as a result of his drunken delirium he accidentally switches trains on his way to Petuški and unknowingly returns to the very city that he has been trying to flee toward the light. Venja's mistaken assumption that he has arrived in the paradise of Petuski, while in fact he is back in the hell of Moscow, creates a nebulous and mystical transition zone 
where heaven and hell are fused. This eery geographic conflation is indicated by the last chapter headings:

ПЕТУШКИ. ПЕРРОН; ПЕТУШКИ. ВОКЗАЛЬНАЯ ПЛОЩАДЬ; ПЕТУШКИ. САДОВОЕ КОЛЬЦО; ПЕТУШКИ. КРЕМЛЬ. ПАМЯТНИК МИНИНУ И ПОЖАРСКОМУ; МОСКВА-ПЕТУШКИ. НЕИЗВЕСТНЫЙ ПОДЪЕЗД (1989: 499-505)

This corresponds to D. Bethea's notion of the "threshold city, the end of history's road where all paths converge as history prepares for eschatological change [...] where, to apply Eliade's terminology, the 'profane center' (e.g. the Whore of Babylon) and the 'sacred center' (the New Jerusalem) meet [...]" (1989: 45).

One of the most intriguing hypotheses made by D. Bethea is that the four men who kill Venja in Moscow may constitute an allusion to the Four Horsemen of the Apocalypse from Revelation 6 (Bethea 1989: 275). This possible parallel is conceivable not only because of their number or their role as destroyers and agents of The End who, according to the Johannine text, are "given power over a fourth of the earth to kill by sword, famine and plague, and by wild beasts of the earth" (Revelation 6: 8). It is also the namelessness of Venja's executioners, and especially the reference to the fourth one, that may evoke the image of the four apocalyptic killers:

\begin{abstract}
И тут началась история, страшнее всех, виденных во сне. В этом самом переулке навстречу мне шли четверо... Я сразу их узнал, я не буду вам объяснять, кто эти четверо... [...] А четвертый был похож... впрочем, я потом скажу, на кого он был похож.
\end{abstract}

(1989: 503)

Thus, these are not just some four thugs but rather four well-known executioners or The Executioners. And the fourth destroyer appears to be the most horrible of all: in fact so horrible that Venja cannot bring himself to identify him. If, as Bethea hypothesizes, we are in fact dealing with an allusion to the fourth Horseman of the Apocalypse, then the stress placed by the hero on this killer would evoke the following passage from Revelation 6: 7: "When the Lamb opened the fourth seal, I heard the voice of the fourth living creature say, 'Come!' I looked, and there before me was a pale horse! Its rider was named Death..." Thus, in this interpretation the fourth executioner is the ultimate bringer of The End.

The role of four executioners at the end of the world and the unique nature of the fourth killer can be also linked to the book of Daniel in the Old Testament, an eschatological text which was a major source of inspiration for 
John's Apocalypse. In Daniel's prophetic dream the visionary sees "four great beasts" who are messengers of doom. Daniel isolates the fourth beast from the rest:

After that, in my vision at night I looked, and there before me was the fourth beast - terrifying and frightening and very powerful. It had large iron teeth; it crushed and devoured its victims and trampled underfoot whatever was left. It was different from all the former beasts, and it had ten horns.

(Daniel 7: 7)

While Bethea's hypothesis about Venja's destroyers cannot be verified - Paperno and Gasparov, for example, see these killers as a possible allusion to the four "titans" of communism: Marx, Engels, Lenin and Stalin (1981: 390 ) - there is a passage in the text which is much easier to link with the book of Revelation and the apocalyptic tradition. It is part of Venja's conversation with Semenyc, the ticket control officer whose arrival on the scene marks the beginning of the horrible events that lead the hero to The End. As all the other passengers, Venja is ticketless and therefore potentially in danger of being fined by Semenyc. Semenyč, however, never fines anyone if he is bribed with vodka. And so, in order to avoid bribing Semenyč, Venja distracts his attention with yarns and fables of all kinds:

И так продолжалось три года, каждую неделю. На линии "Москва-Петушки" я был единственным безбилетником, кто ни разу еще не подносил Семенычу ни единственного грамма и тем не менее оставался в живых и непобитых. Но всякая история имеет конец, и мировая история тоже... $(1989: 477)$

The last sentence with its allusion to the end of the world paves the way for Venja's apocalyptic "yarn of the day", which is a parodic version of the tone and also certain specific places in Revelation:

“От третьего рейха, четвертого позвонка, пятой республики и семнадцатого съезда ${ }^{3}$ - можешь шагнуть, вместе со мнои, в мир вожделенного всем иудеям пятого царства, седьмого неба и второго пришествия?..” “Могу!” рокотал Семеныч. “Говори, говори, Шехерезада!" “Так слушай. То будет день, 'избраннейший из всех дней'. В тот день истомившийся Симеон скажет наконец: 'Ныне отпущаеши раба Твоего, Владыка...' [...] И все чье имя вписано в книгу жизни запоют 'Исайа, ликуй!', и Диоген погасит свой фонарь. И будет добро и красота, и все будет хорошо, и все будут хорошие, и кроме добра и красоты ничего не будет, и сольются в поцелуе [...] мучитель и жертва; 
и злоба и помысел, и расчет покинет сердца, и женщина [...] Востока сбросит с себя паранджу!"

(1989:477-478)

In addition to the clearly apocalyptic associations evoked by the Third Reich, The Second Coming and the prophetic tone of the hero's visionary outburst, Venja's ranting about those whose name is written in the "book of life" ("kniga žizni") and the bliss that they will enjoy may be linked with the following passages from Revelation 20 and 21:

Another book was opened, which is the book of life. [...] The sea gave up the dead that were in it, and death and Hades gave up the dead that were in them, and each person was judged according to what he had done. [...] If anyone's name was not found written in the book of life, he was thrown into the lake of fire. [...] Now the dwelling of God is with men, and he will live with them. [...] He will wipe every tear from their eyes. There will be no more death or mourning or crying or pain, for the old order of things has passed away. ${ }^{4}$

The parodic style of all the above-cited biblical allusions and pseudoJohannine "prophecies" takes nothing away from the seriousness and horror of Venja's doomsday. As in a great number of other instances, Venja's references to the Bible are a mixture of mockery and reverence, desecration and veneration, which, according to $C$. Simmons, is merely a device associated with our ironic age: "True to the spirit of the story, Erofeev displays once again the (modern) tendency to desecrate the sacred (here, the holy writ), while still longing to worship it" (Simmons 1990: 161). ${ }^{5}$ And, judging from an interview given by Erofeev shortly before his death, the Bible was clearly the spiritual center of his life. As Erofeev points out,

[...] для меня эта книга есть то, без чего невозможно жить. Я из нее вытяннул все, что можно вытянуть душе человеческой, и не жалею об этом.

According to D. Bethea allusions to the biblical end of the world, such as those discussed above, are typical of apocalyptic fiction where references to the Johannine text invite the reader "to view the mythic 'zone' of novelistic space (i.e., the themes, figures and passages taken from Revelation) and the realistic 'zone' of novelistic space (i.e., the openness and contingency of contemporary life and history) as being in profound dialogic interaction" (Bethea 1989: 34). This dialogic interaction is a key element of Bethea's notion of the "apocalyptic plot" where the end, in dialogue with The End, gives special meaning to the story. He argues that an apocalyptic plot is 
"in a fundamental way about the End [... and] the reader of these works is drawn to see a connection between personal death and the end of national, even world history" (39). ${ }^{6}$ All of this can be applied to Moskva-Petuški not only because of the apocalyptic nature of the hero's death, but also because the entire structure of the narrative is based on a trip whose destination is the end of a train line, which leads to the end of a life and the end of a story. Read in this manner, Venja's trip toward The End becomes a Bakhtinian chronotope, evoking the spatio-temporal "put" concept, which gained prominence especially in Russian nineteenth-century apocalyptic thought. As D. Bethea points out:

[...] the almost hypnotic attraction of the put', with its spatialization of temporal desire, is an essential ingredient in the messianic and apocalyptic roles that the nineteenth-century intelligentsia assigned to the long-suffering narod. It was felt that the various roads, paths, and ways invoked to describe Russian historical time should in the end, and at the end, have a destination.

(Bethea 1989: 27)

The key element in Venja's "put" is the train which acts as a spatiotemporal vehicle bringing the hero and the story to The End. D. Bethea accords special attention to the train and its predecessor, the horse, in apocalyptic fiction, arguing that in the minds of eschatologically-minded Russian authors the horse/train image has had particular significance since the nineteenth century:

Taking their cue from perhaps the best-known of all passages Revelation 6: 1-8, which depicts history's movement through four stages of horse and rider - these novelists develop elaborate symbolic networks around the image of the horse and its modern counterpart, the train ("the iron horse") [... which is] an ideal symbol for eschatological transit, for the tumultuous "ride" from one space-time to another.

(Bethea 1989: 46-47)

In this connection Erofeev's text can be seen as the embodiment of Russian apocalyptic fiction because a train, and specifically a train ride to The End, is not merely part of the novel: it is the novel - both structurally and thematically.

While in the beginning of Moskva-Petuški Erofeev takes the train, i.e., appears to be in control, after the episode with Semenyc the train ends up taking the hero toward his apocalypse. The helplessness of the hero being drawn toward The End by a spatio-temporal doomsday machine appears to be a key 
element of D. Bethea's understanding of the eschatological role of the train image in Russian apocalyptic fiction:

Now the rider does not hold the reins but is driven by a diabolical machine toward the terminus of death [...] The train is so threatening a symbol of doom (in the popular consciousness it was given not the neutral name poezd, but the marked one, mashina - the ultimate machine and handiwork of the Antichrist) because it moves, like "atheistic" logic, along iron rails without any higher reason for being [...]. The train continues to be a powerful, and often apocalyptically colored symbol for both the popular and literary imagination well into the twentieth century: there is, for example, [...] Venedikt Erofeev's tragicomic tale, punctuated with allusions to Revelation, of another doomed train-ride into alcoholic oblivion and death [...]. Thus, perhaps more than any other single ingredient of the apocalyptic plot it is the "chronotopic" picture of the horse/train that has had the most farreaching implications for the shape of the various authors' thinking as inscribed in the movement of the different stories.

(Bethea 1989: 58-59)

Thus, shaping the "movement" of Moskva-Petuski, the train in the second half of the text turns into an infernal doomsday machine, which may account for Venja's confrontation with the biblical Beast. During the hero's drunken delirium he encounters Satan who tries to tempt Venja:

Ты лучше вот чего: возьми и на ходу из электрички выпрыгни. Вдруг да не разобьешься...

$(1989: 488)$

This appears to be an allusion to the temptation of Christ from Matthew 4: 5:

Then the devil took him to the holy city and had him stand on the highest point of the temple. "If you are the Son of God," he said, "throw yourself down. For it is written: "He will command his angels concerning you, and they will lift you up in their hands, so that you will not strike your foot against a stone'."

Likewise, Venja is threatened by a creature whom he calls the Sphinx but whose description appears to have a demonic connotation and may even evoke the image of the fantastic Beast out of the Sea from Revelation 13:

Чуть только я забылся, кто-то ударил меня хвостом по спине. Я вздрогнул и обернулся: передо мною был некто без ног, без хвоста и без головы.

(1989: 489-490) 
The train ride in Moskva-Petuskki is closely linked with the hero's gradual intoxication which causes him to sink deeper and deeper into delirium. In other words, just as the train brings Venja to Moscow and Petuški at the same time, i.e., to the above-mentioned "threshold city" or mystical transition zone, alcohol too places the narrator into a utopic (nowhere) state. Whereas in the beginning Venja is clearly in this world - dealing with the recognizably Soviet hostile restaurant staff at the Kursk station or sitting and chatting with other alcoholics travelling on the same train - after the meeting with Semenyc, the train and the hero's intoxication shift him into a no-man's land from which he never emerges. This transition is indicated first of all by the fact that Venja suddenly finds himself completely alone on the train, while day has inexplicably turned into menacing night: "“Est' $u$ nas cto-nibud' vypit', Petr?' 'Net ničego. Vse vypito.' 'I vo vsem poezde net nikogo?' 'Nikogo"' (1989: 497). This conversation takes place not with a fellowpassenger from the recognizable real world but with an otherwordly valet nained Petr who is part of Venja's alcoholic visions. Other utopic characters encountered by the hero in this eery world are a mysterious nineteenthcentury princess dressed in black, Satan, the demonic Sphinx and a host of Furies. ${ }^{7}$ Because Venja enters this mystical zone while on a regularly scheduled trip between two real-world cities, his location corresponds to what $E$. Leach refers to as a "betwixt and between locality described as in the wilderness', which is neither fully in This World nor in The Other" (quoted in Bethea 1989: 46). According to Leach, in our mythology such a zone of "betwixt and between" is where an inspired prophet comes face to face with God or experiences revelation. And D. Bethea points out that intoxication is a common means by which such a state of mystical delirium is achieved in apocalyptic fiction (1989: 46). ${ }^{8}$

Quite apart from these foreboding events is a period of bliss experienced by Venja before the beginning of the main story line. It consists of twelve weekly encounters with his beloved and their little son in Petuski: the trip described in this story is the demonic thirteenth. To the hero these twelve Fridays are like a glimpse of a Golden Age:

Все ваши выдумки о веке златом, - твердил я, - все ложь и
уныние. Но я-то, двенадцать недель тому, видел его прообраз,
и через полчаса сверкнет мне в глаза его отблеск - в три-
надцатый раз. Там птичье пение не молкнет ни ночью, ни
цнем, там ни знмой ни летом не отцветает жасмин [...]. (1989:479)

Venja's Golden Age corresponds to D. Bethea's "period of grace", which he sees as a common feature of the typical apocalyptic plot: "In each of these novels the period of innocence or grace is 'not of this world' and is 
experienced as a separate, enclosed epic past which took place prior to the principal action and which preceded the hero's and/or heroine's 'fall into' history [...]" (1989: 40). Bethea implies that this period of grace cannot be regained: it is an Eden lost forever. In the same way Venja can never make it to Petuski no matter what he does.

As the foregoing indicates, Moskva-Petuski is saturated with biblical allusions and imagery. ${ }^{9}$ However, Venja's death lacks a key element of the biblical narrative and especially of John's Revelation, for his apocalypse is without hope, i.e., without resurrection. By stressing the disappearance of his consciousness at the moment of his grotesque crucifixion, Venja not only makes his narrative "impossible", but also indicates that there is nothing after his death. Thus, his End becomes much more terminal than even the most cataclysmic carnage in the book of Revelation. Whereas the Johannine visions are followed by humanity's return to Heaven via New Jerusalem and eternal conscious bliss, Venja is denied access to his paradise and sinks into unconscious oblivion. As a result, Venja undergoes an experience outside the Judeo-Christian tradition: something like an atheistic Apocalypse. This is all the more paradoxic because throughout the text the hero sees himself as an alcoholic Christ.

As Paperno and Gasparov demonstrate, the key to Venja's Christ-like identity is the phrase "talifa kumi":

“Встань и иди" ("Талифа куми") - слова Иисуса, обращенные к
воскрешеннои,, - многократно повторяются в повести. Впер-
вые их произносит повествователь, обращаясь к самому себе, в
первой главе, когда, проснувшись в чужом подъезде, он выхо-
дит из него на воздух. "Иди, Веничка, идн" - это один из мно-
гочисленных вариантов "талифа куми", проходящих через всю
повесть. (1981:387)

Given that the Venja-Christ parallel is repeatedly drawn throughout the text, among the numerous allusions to the New Testament in Erofeev's novel one of the most important has to do with the crucifixion. Notably, Venja's death and trip toward The End take place on Friday. Before he is confronted by his four executioners, in one of his delirious visions Venja's side is pierced by an imaginary character whom the hero calls "pontijskij car' Mitridat" (1989: 499-500) and who, according to Paperno and Gasparov (1981: 399), is merely a modified version of Pontius Pilate. Just before being murdered Venja asks God the question that Christ puts to his creator on the cross in Matthew 27: 46: 
[...] лама савахфани, как сказал Спаситель... То есть: “Для чего, Господь, Ты меня оставил?” Для чего же все-таки, Господь, ты меня оставил? Господь молчал.

(1989:506)

Thus, while Christ is raised from the dead by the Lord in answer to his question, Venja's question is followed by sterile atheistic silence. Venja's last sentence - "i s tech por ja nikogda ne prichodil v soznanie, i nikogda ne pridu" - confirms the implication that the afterlife is impossible in the hero's world. This image of an unresurrected Christ, an unsaved savior, suggests a particular kind of End. Venja's End takes only the terminal aspect of the Judeo-Christian eschatological tradition and excludes the idea of a new beginning which is so essential to the Johannine text. And in this respect, Venja's sterile apocalypse may be a reflection of the violently atheistic society in which the action of the novel takes place: Venja undergoes a Soviet materialistic version of The End.

I would like to conclude this discussion by proposing that MoskvaPetuski can be viewed as a paradigmatic text in the framework of F. Kermode's notion of the Apocalypse in literature. Kermode cites the work of J. Marsh and $\mathrm{O}$. Cullmann with respect to two key terms related to the passage of time - chronos and kairos: "chronos is 'passing time' or 'waiting time' that which, according to Revelation, 'shall be no more' - and kairos is the season, a point in time filled with significance, charged with a meaning from its relation to the end" (Kermode 1967: 47). According to Kermode chronos is the uninterrupted time of everyday existence, a kind of background to something more important, i.e., kairos. And literary narratives are attempts to transform chronos into a series of kairoi:

Let us take a very simple example, the ticking of a clock. We ask what it says: and we agree that it says tick-tock. [...] The fact that we call the second of the two related sounds tock is evidence that we use fictions to enable the end to confer organization and form on the temporal structure. The interval between the two sounds, between tick and tock is now charged with significant duration. The clock's ticktock I take to be a model of what we call a plot [...]. Tick is a humble genesis, tock a feeble apocalypse [...].

(Kermode 1967: 44-45)

Kermode presents the Old and New Testaments as the main narrative paradigm for Western literature, arguing that the apocalyptic archetype, i.e., "the End, changes all, and produces, in what in relation to it is the past, these seasons, kairoi, historical moments of intemporal significance. The divine plot is the pattern of kairoi in relation to the End" (1967: 47). Moskva-Petuški, from its title to its structure is a Kermodian plot with Venja's departure 
from Moscow as the tick and his arrival in Moscow-Petuski as the tock. Venja's ever-moving train connecting The Beginning and The End is chronos, which is transformed into kairos by The End, i.e., it is the hero's apocalyptic death that turns the train into an infernal chronotope and therefore confers special significance on all the events of the novel. If Kermode is suggesting that meaning is ultimately derived from literary texts when they are viewed backwards from their endings, then Venedikt Erofeev's text is indeed the literary essence of The End.

\section{NOTES}

$1 \quad$ Also cf. T. Todorov (1966: 125-151) and G. Genette (1966: 152-163).

2 Regarding the Petuski-Eden parallel, cf. P. Vajl and A. Genis (1982: 42, 48). Also cf. I. A. Paperno and B. M. Gasparov (1981: 388).

3 N. Cohn points out the link between the Nazi concept of the Third Reich and the apocalyptic prophecies of the extremely influential Calabrian abbot Joachim of Fiore (1145-1202) who saw "history as an ascent through three successive ages, each of them presided over by one of the Persons of the Trinity. The first age was an Age of the Father or of the Law; the second age was the Age of the Son or the Gospel; the third age would be the Age of the Spirit and that would be the culmination of human history" (Cohn 1961: 100).

As for the 17th Congress - clearly a reference to the 17th Congress of the Soviet Communist Party which took place in January-February 1934 - its presence in this apocalyptic list is "eschatologically" appropriate, since it can also be linked with the End of the world. This congress and the year 1934 marked the beginning of the most horrible period of terror under Stalin when millions of people were eliminated or imprisoned. The events following the 17th Congress constituted a Soviet Armageddon whose scale of destruction, murder and suffering can be likened to the End of the world.

4 Could Venja's presumably metaphoric Woman of the East ("Ženščina vostoka") allude to John's references to the metaphoric Woman and the Dragon and Woman on the Beast in Revelation 12 and 17 respectively? Cf.

[Евангельские мотивы повести] нередко приобретают оттенок пародии, шутки, каламбура: высокое и трагическое неразрывно сплетаются с комическим и непристойным.

(Paperno and Gasparov 1981: 389) 
6 On personal death as an apocalypse cf. F. Kermode (1967: 24-25).

7 As Paperno and Gasparov correctly point out, in Venja's state of delirium "struktura perekladyvanija èlementov 'real'nosti' v bred predel'no obnažena" (1981: 399).

8 Simmons (1990) provides an impressive socio-aesthetic discussion of the role of alcohol in Moskva-Petuški and in Soviet society.

9 Cf. Smirnova (1990: 58-66).

\section{REFERENCES}

Al'tšuller, $\mathbf{M}$.

1982 'Moskva-Petuski V. Erofeeva i tradicii klassičeskoj poemy'. Novyj Žurnal, Vol. 146, pp. 75-85.

Benveniste, E.

1966 Problèmes de linguistique générale. Paris.

Bethea, D.

1989

Chatman, S.

1978

Cohn, D.

1978

Cohn, N.

1961 In Pursuit of the Millennium: Revolutionary Messianism in Medieval and Reformation Europe and its Bearing on Modern Totalitarian Movements. New York.

Eco, U.

The Shape of the Apocalypse in Modem Russian Fiction. Princeton, N.J.

Story and Discourse: Narrative Structure in Fiction and Film. Ithaca, N.Y.

Transparent Minds: Narrative Modes for Presenting Consciousness in Fiction. Princeton, N.J.

1984 The Name of the Rose (Transl. W. Weaver). New York.

Erofeev, V.

1989 Moskva-Petuški. Vest' (Eds. L. Gutman et al.). Moskva.

Genette, G.

1966

Kermode, F.

1967 The Sense of an Ending: Studies in the Theory of Fiction. New York.

Lanser, S.

1981 The Narrative Act: Point of View in Fiction. Princeton, N.J.

Paperno, I. A., Gasparov, B. M.

1981

'Vstan' i idi'. Slavica Hierosolymitana, Vol. V-VI, pp. 387-400. 
Romberg, B.

1962

Studies in the Narrative Technique of the First-Person Novel. Stockholm.

Simmons, C.

1990

"An Alcoholic Narrative as "Time Out" and the Double in Moskva-Petushki'. Canadian-American Slavic Studies, Vol. 24, Sum-

Smirnova, E. A. mer, pp. 155-168.

1990

'Venedikt Erofeev glazami gogoleveda'. Russkaja literatura, No.

Todorov, $\mathrm{T}$.

3, pp. 58-66.

1966

'Les catégories du récit littéraire'. Communications, Vol. 8, pp.

Tosunian, I. 125-151.

1990

Vajl, P., Genis, A

'Ot Moskvy do samych Petuškov'. Literaturnaja gazeta, Jan. 3, No. 1, p. 5.

1978

1982

'Strasti po Erofeevu'. Echo, Vol. 4, pp. 109-117.

1988

Sovremennaja russkaja proza. Ann Arbor.

60-e: Mir sovetskogo celoveka. Ann Arbor. 